\title{
EMBARKING DIGITAL LEARNING DUE TO COVID-19: ARE TEACHERS READY?
}

\author{
David Sulistiawan Aditya (iD \\ Universitas Aisyiyah Yogyakarta (Indonesia) \\ davidsaditya@unisayogya.ac.id
}

Received September 2020

Accepted December 2020

\section{Abstract}

The COVID-19 pandemic has resulted in school closures all over the globe and forced students to embark on digital learning to ensure learning continuity. The implementation of digital learning on educational settings has posed challenges particularly for developing countries to improve human resources and infrastructure. On this basis, this study explores the teacher readiness in conducting digital learning in Yogyakarta, Indonesia. This exploratory study employed an online questionnaire and semi-structured interviews via either voice or video calls to safely gather data from K-12 teachers of 27 different schools in the middle of the pandemic in Yogyakarta. This study found that the teachers perceived they were psychologically, technologically, and pedagogically ready to conduct digital teaching and learning. This study also discovered that the digital learning problems were mostly encountered by teachers in rural areas. Another problem was generated from the different levels of students' affordance of technology that mainly led to digital learning inequality. Therefore, this study proposed an alternative choice of technology and teaching methodology to adopt and to adjust as a solution to the occurring learning problems. In addition, it also discussed the teachers' perceptions of digital learning.

Keywords - Digital learning, COVID-19, Teacher readiness.

\section{To cite this article:}

Aditya, D.S., (2021). Embarking digital learning due to COVID-19: Are teachers ready? Journal of Technology and Science Education, 11(1), 104-116. https://doi.org/10.3926/jotse.1109

\section{Introduction}

The outbreak of novel coronavirus 2019 (COVID-19) has impacted on many aspects globally, including education. The epidemic has not only infected 287,176 people and recorded 11,890 mortality rate on 21 March 2020 (worldometers.info, 2020), but also impacted on the global economy, markets (Lee, 2020) and education (Cao, Fang, Hou, Han, Xu, Dong et al., 2020). The Covid-19 spread out rapidly to more than a hundred countries and put a hundred thousand people at the risk of death from the infection (worldometers.info, 2020). Many countries responded to this condition by issuing a policy to mitigate and overcome this full-blown pandemic through temporary closure of the educational institutions. The closure impacted more than 421 million children all around the world (Tam \& El-Azar, 2020). A million number of students were regulated to do distance learning. Indonesia is one of the countries that made the same policy to its educational institutions. Around 45.3 million students in Indonesia (Statistik, 2019b) are affected by the school closures. The closure is scheduled from 17 March until unspecified time depending 
on the situation. Consequently, schools are required to conduct distance and digital learning to ensure education continuity for students during the closure as instructed by the Minister of Education and Culture of Republic of Indonesia sentenced in the circular number 4, 2020 and signed on 24 March 2020.

The sudden decisive policy may lead to problems if teachers were not ready to facilitate digital learning in the middle of the pandemic. Most of Indonesian teachers have been found to lack of sufficient technological skills (Copriady, 2014). The data from the 2012 Teacher Competence Test (UKG) reported that the national average score of teachers were $47.84 / 100$. The result was below the passing grade of $70 / 100$, indicating that teachers were deprived of technological skills (Abidin, Mathrani, Hunter, \& Parsons, 2017). Central Bureau of Statistics of Indonesia in 2018 informed the updated data after several years. The ICT development index in Indonesia was considered still low with 5,07 on a scale of 1-10 with individual technological skill of 5.76 (Statistik, 2019a). Thus, the individual's technological skills should also be the concern in creating distance learning policy (Tang \& Tseng, 2013). This ideal notion particularly applies for teachers since it is difficult for them to be familiar with the growing number of available ICT tools let alone to effectively use them as the supporting facilities in teaching and learning (Redmond \& Lock, 2019). Therefore, teachers need to develop their technological knowledge and skills to integrate technology into their teaching.

Regardless of the education policy, it is no longer true to consider that most of Indonesian teachers are deprived of adequate technological skills (Copriady, 2014) since today's teachers have always been eager to gain more knowledge and skills on technology in mobile learning (Yusri, Goodwin, \& Mooney, Teachers and mobile learning perception: towards a conceptual model of mobile learning for training, 2015) and there have been many emerging innovations in integrating mobile technologies. Technology provides teachers with unlimited potential to transform and improve their teaching practices (Leach, Ahmed, Makalima, \& Power, 2005). Likewise, Yusri, et.al. (2015) revealed that most Indonesian teachers have a positive perception on mobile learning. They also reiterated that financial and technological affordance issues were no longer a problem given teacher's engagement in a mobile learning environment. Similarly, Abidin et al. (2017) in his study found that Indonesian teachers have positive perceptions on the use of mobile technology in classroom instruction although most of them are concerned about the ethical issues during classroom instruction. Therefore, it is essential to study the present teacher readiness and challenges in digital learning to formulate better policies in the current pandemic situation.

Digital learning in this study is either a systematic or spontaneous process of acquiring knowledge or skills by making effective use of any types of technological devices like smartphones, tablets, computers, or others. It covers the application of various practices, including distance, blended, and virtual learning. Considering the gap between the statistical data and the studies of low teachers' technological competency, and the teachers' positive perception and potential transformation in digital learning, this study understands teacher readiness in managing the digital learning due to school closures policy in Yogyakarta, Indonesia. This study also describes teachers' beliefs and doubts in conducting digital learning. Teacher readiness is interpreted from three aspects i.e. technological, pedagogical, and psychological aspects (Abidin et.al., 2017). An online questionnaire in the form of both close and open questions was employed to gather quick data safely during the pandemic. Interviews via voice and video calls were conducted to better understand teacher readiness and challenges in digital learning. Thus, this study can be one of the considerations in digital learning implementation in Indonesia as it will answer two questions:

1. To what extent do teachers use digital technology in the teaching and learning process?

2. How have their experiences and perceptions influenced their readiness in digital learning?

\subsection{Indonesian Education Policy Amidst the Pandemic Crisis}

Since two Indonesians were confirmed positive of COVID-19 on 2 March 2020, the central and local government have made some policies in regard to the continuity of Indonesian education. The ministry 
of education and culture of the Republic of Indonesia issued the first circular No. 3 on 9 March 2020. This circular informed all education institutions in Indonesia related to school protocols to prevent the virus transmission in education areas (Kemdikbud, 2020b). Considering the rising trend of the infection rate, some local governments took their own initiatives to close schools to prevent the spread. The school closure policy has been particularly enacted since 16 March 2017 in the area at the center of outbreak, such as Jakarta and West Java (Getty, 2020). A few days after, the ministry of education and culture issued a circular No. 4 to impose lockdown on all Indonesian schools and to start digital learning since 24 March 2020 , which was further enacted by all local governments. These closures have forced around 45.3 million students in Indonesia to study from home (Statistik, 2019a).

The last circular contains six points on policy and guidance for Indonesian education institutions in the teaching and learning process. First, the national examination is cancelled and replaced with other forms of assessment. Second, the learning from home process is conducted online and the learning materials can be focused on life skills education and COVID 19 pandemic. Third, semester tests and other forms of tests that require students to gather are prohibited and shall be conducted via online or through report cards. Fourth, semester examinations for student promotion should avoid gathering students and shall be done through portfolio reports or other forms of assessments. Fifth, the school enrolment (PPDB) can be conducted if the local education department has already prepared a school enrolment mechanism with the Covid-19 protocols. Sixth, the School Operational Assistance Funds can be used to manage the COVID 19 prevention program. The circular imposed that all school activities be conducted via digital media. However, the policy has led to some technological problems, such as technological affordances and difficult internet access for the learning process. Media coverage highlighted the impact of technological problems in some areas in Indonesia, particularly related to students' difficulties in accessing online learning due to unequal access to facilities and infrastructure.

In response to the problems at stake, the government launched a TV program called 'Belajar dari Rumab' in one of Indonesian public TV stations (Ernes, 2020). This enable students who cannot gain an access to online learning to watch the TV program based on their school's levels and schedules. The TV program, 'Belajar dari Rumah', is aired from Monday to Friday. It provides six different learning programs designed based on the cohorts of students' school levels and based on the National curriculum. The learning cohorts are first - third grade of primary schools, fourth - sixth grade of primary schools, secondary school, high school, and parenting program. The TV program is scheduled to air for three hours per day. Every learning group is scheduled to learn from the TV program for 30 minutes. The Indonesian Ministry of Education appealed parents and students to leverage this program for learning from home (Kemdikbud, 2020a).

\subsection{Digital Learning}

Digital learning in this study covers either a systematic or spontaneous process of acquiring knowledge or skills by making effective use of any type of technological devices like smartphones, tablets, computers, or others. Sousa \& Rocha (2019) discussed digital learning from two views. In the first view, they referred to a theory that defined this term as an unplanned and spontaneous process of learning using technological devices. It provides learners with critical thinking, collaboration, and independence in learning albeit lacking of any learning objectives. On the second view, they considered digital learning as a planned process when organizations set up a specific course. In their account, the planned activities are usually combined with spontaneous learning activities, such as searching for information, watching videos, or others. In the education context, materials provided through digital learning offer more possibilities in teaching which may never take place in face-to-face classroom instruction such as place- and time- independency in learning (CZwart, Noroozi, Van Luit, Goei, \& Nieuwenhuis, 2020).

Pandemic has required the uptake of digital learning in education as a way to apply health protocol of physical distancing in the attempt to stop the spread of COVID-19. Here, teachers play a crucial role in the dramatic change from face-to-face classroom instruction to digital learning in the provision of digital learning materials (Tsybulsky \& Levin, 2019). Teachers should be able to assist learners with 
technological problems in digital learning (Compton, 2009). Teachers' ability to use learning software and hardware and effective communications to motivate students in learning are the key aspects to encounter these problems (Gray, Ryan, \& Coulon, 2004). Towards this end, teachers should have sufficient technological knowledge. If the pandemic changes what Tsybulsky \& Levin (2019) call a new "worldview" in education, in this context, a teacher also plays a key role in influencing the younger generation's new worldview of learning. The worldview here is the paradigm to change human consciousness and integrate novel technologies in learning, which may never happen without a collection of teachers' beliefs (Tsybulsky \& Levin, 2019).

\subsection{Teacher Readiness in Digital Learning}

Teacher readiness is seen from three different aspects i.e. technological, pedagogical, and psychological aspects (Abidin et al. 2017). The aspects are interpreted from barriers and limitations of mobile and digital learning discussed in a study conducted by Stockwell (2008) and Wang and Higgins (2006). Technological problems are mostly coming from technological devices characteristics and supporting infrastructures. Wang and Higgins (2006) mentioned five main problems of learning using mobile technology: small screen and resolution, input limitation (language text input), internet access, compatibility, and additional limitations such as memory and storage, price, network facility, etc. Differently, Abidin et.al. (2017) defined technological readiness as teacher's technological skills. It is the teacher's ability of utilizing technological software and hardware and to the extent of their comfort to use it to facilitate teaching. In this context, technological readiness considers this technical readiness as well as technological skills of the teachers.

Meanwhile, the characteristic of digital learning, which emphasizes more on autonomous, independent, and self-directed learning leads to pedagogical limitation (Wang \& Higgins, 2006). Its nature of being taken place anytime and anywhere makes it difficult to follow up and to measure its achievements. Hence, the pedagogical aspect in this study is interpreted through the lenses of knowledge of manipulating technological tools or media in a more student-centered learning environment. The student-centered learning theory delineates teacher roles to select tasks, assist student's collaboration, and provide formative feedback (Pakdaman-Savoji, Nesbit \& Gajdamaschko, 2019). In other words, the teacher's pedagogical readiness is negotiated into these roles. Last, psychological readiness is about the affective side of using technology in teaching. It is more about how motivated teachers integrate technology and view this as a potential habit to support learning (Wang \& Higgins, 2006). Copriady (2014) in his study also observed that teacher's attitudes are psychological factors that influence teacher's decisions to integrate technology. The psychological barrier is considered a more difficult barrier to overcome as it is related to selfmotivation and beliefs (Stockwell, 2008).

\section{Methodology}

This study employed an online questionnaire to survey the K-12 teachers' experiences in conducting digital education due to school closure during the pandemic. Safety was also another main reason to utilize this form of questionnaire for the data collection. The questionnaire was adapted from the previous research conducted by (Abidin et al., 2017) in investigating mathematic teachers' experiences and perceptions of integrating mobile technology, The questionnaire consisted of 29 items, including both closed and open-ended questions. The questions were subjected to gather qualitative data to prescribe the teachers' experiences. These questions were divided into three categories i.e. participant characteristics, background of teaching experiences, and teacher's experience in digital learning.

This study employed non-probability sampling technique to gather initial data and to define the purposive samples for the semi-structured interview. The interview was aimed to deepen understanding of digital learning problems. The study was conducted to K-12 teachers of both public and private schools in Yogyakarta. The link of the online questionnaire was randomly distributed through school principals' and teachers' social media groups in the coordinator area of Yogyakarta. $62 \mathrm{~K}-12$ teachers gave responses to the questions. The teachers participating in the questionnaire were affiliated to 27 different schools (4 primary schools, 3 secondary schools, and 20 high schools). 43 were from schools 
in urban areas and 9 were from rural schools. Five of the teachers ( 3 from urban and 2 from rural) were interviewed via either voice or video calls to gain further teachers' perceptions. The five met the inclusion criteria i.e. he or she is an active teacher, uses digital technology in teaching, represents the five groups of years of service, represents the range of age groups, represents rural and urban schools, and is willing to be interviewed.

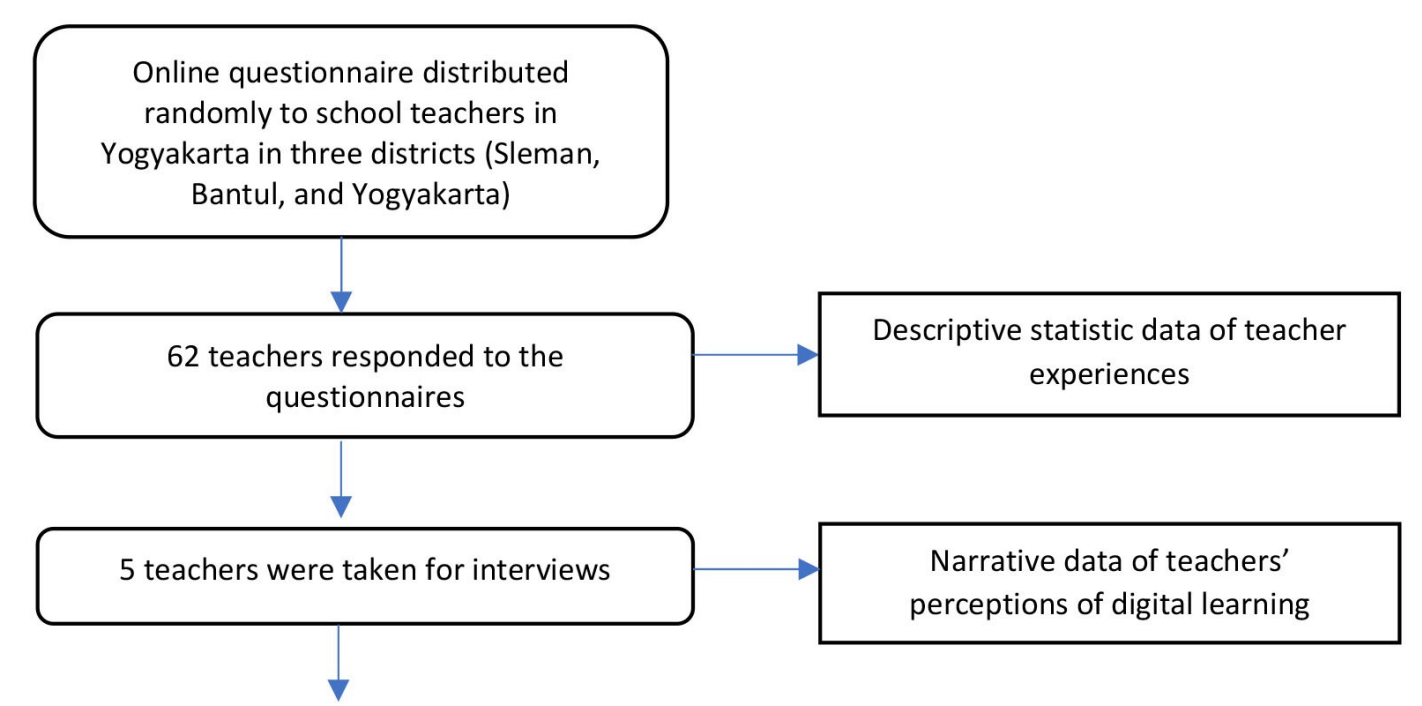

\begin{tabular}{|c|c|c|c|c|c|}
\hline No & Participants & Age group & Years of service & School type & School Location \\
\hline 1 & T1 & Under 30 & Less than 1 year & Senior High School & Rural \\
\hline 2 & T2 & $30-39$ & $1-5$ years & Elementary School & Urban \\
\hline 3 & T3 & $40-49$ & $6-10$ years & Junior High School & Urban \\
\hline 4 & T4 & $40-49$ & $11-15$ years & Senior High School & Rural \\
\hline 5 & T5 & 50 or more & More than 15 years & Senior High School & Urban \\
\hline
\end{tabular}

Figure 1. The number of participants and sample

The data gained from the questionnaire were coded and then analysed using descriptive statistics. The results were subjected to understand the teachers' experiences in leveraging digital technologies in teaching and learning. Meanwhile, the data from the interviews were transcribed verbatim and analysed in Indonesian language. The researcher immersed in the data to become familiar with it by reading and re-reading through the data. Then, the data were categorized into emergent themes. Every response was coded and grouped into categories. The categories with more responses were marked as prominent. The categories were then identified for patterns and trends. The identified categories were used to delineate more understanding of the teacher readiness through their perspectives and experiences.

\section{Results}

\subsection{Teachers Demography Profile}

The teachers in this study consisted of 47 males $(75,8 \%)$ and 15 females $(24,2 \%)$. Most of them were in the age category of between 40 and 49 years old $(30.6 \%)$. The others were in the age group of between $30-39$ years old $(29 \%)$, above $50(29 \%)$, and under $30(11 \%)$. In terms of teaching experiences, most of them have been teaching for more than 15 years $(45.2 \%)$. The others have been teaching for 11-15 years (24.2\%), 6-10 years (14.5\%), 1-5 years (14.5\%), and less than 1 year (1.6\%). They mostly handled more than 25 students in their classes $(75.8 \%)$ and the rest handled less than 25 students. 


\begin{tabular}{|l|c|c|}
\hline \multicolumn{1}{|c|}{$\begin{array}{c}\text { Teacher Demography and Background } \\
\text { (N=62) }\end{array}$} & Frequency & Percentage (\%) \\
\hline $\begin{array}{l}\text { Gender } \\
\text { Female }\end{array}$ & 47 & $24.2 \%$ \\
Male & 15 & $75.8 \%$ \\
\hline Age range & 7 & \\
Under 30 & 18 & $11.3 \%$ \\
$30-39$ & 19 & $29 \%$ \\
$40-49$ & 18 & $30.6 \%$ \\
50 or more & 1 & $29 \%$ \\
\hline Years of Service & 9 & $1.6 \%$ \\
Less than 1 year & 9 & $14.5 \%$ \\
$1-5$ years & 15 & $14.5 \%$ \\
6-10 years & 28 & $24.2 \%$ \\
$11-15$ years & & $45.2 \%$ \\
More than 15 years & 6 & \\
\hline Type of School & 4 & $9.7 \%$ \\
Elementary School & 52 & $8.4 \%$ \\
Junior High School & & \\
Senior High School & 43 & $69.35 \%$ \\
\hline Location of Schools & 9 & $14.5 \%$ \\
Urban & & \\
Rural & & \\
\hline
\end{tabular}

Table 1. Information of teachers' demographic profile

\subsection{Teachers' Experiences in Digital Learning}

To explore teacher readiness in digital learning, it is essential to get information on the teacher's experience in utilizing digital technology in their classes. The study found that more than half of the teachers $(59.7 \%)$ integrated mobile technology in their classes from their own initiative and some of them $(32.3 \%)$ reported to use it because of the school regulation due to the pandemic situation. Further, half of them $(46.8 \%)$ admitted that they have integrated technologies for teaching between 1 until 5 years and some $(38.7 \%)$ used it since the school closures this year or for less than a year. They also had quite an intensive frequency in using digital media to support the class instruction. Many of them confessed that they use digital learning 1 to 3 times a week $(62.9 \%)$, and few of them $(11.3 \%)$ even teach students using the digital platform in every meeting due to this situation, and the others $(9.7 \%)$ use it for 4 to 6 times per week.

In terms of facilities and internet access that support the learning continuity, the teachers $(71 \%)$ reported that both teachers and students have mobile technology and have gained an internet access. However, few $(29 \%)$ said that they and their students had limited access to the internet. To manage and get access to the class, most teachers $(87.1 \%$ ) utilized mobile technology (mobile phones) connected to the internet for accessing the class. The data show that many of the teachers and students were well equipped with technology and internet access to support the learning. Also, mobile technology (mobile phones, laptops) were commonly used by the teachers to manage the teaching instructions. However, some of them could not access and manage learning due to limited access and facilities.

To see the quality of the learning instruction through digital learning, the teachers (82.3\%) had enough time to prepare the e-learning material and few of them (17.7\%) admitted that they did not have enough time to prepare any materials for the class. Further, almost all teachers $(90.2 \%)$ actively responded in an online discussion with the students although few $(9.8 \%)$ confessed that they were not active in conducting a discussion. In terms of giving students assignment, most teachers $(96.8 \%)$ gave feedback on students' works but few $(3.2 \%)$ did not. The majority of teachers (73\%) conducted assessment through technological devices although few (27\%) said they did not and not always did that. These findings illustrate the teachers' pedagogical knowledge and readiness in teaching through digital devices as they have time to prepare the teaching materials well enough, actively engage in online discussions, conduct 
assessment, and almost all of them make sure that their students get feedback from their works. Even though few did not do those activities in their teaching with their own reasons.

To explore the teachers' technological knowledge, we enquired which technological devices they mostly used during their teaching. Many of them (69.4\%) used emails for engaging with students' works and assignments, particularly for downloading and uploading learning materials $(64.5 \%)$. A half $(46.8 \%)$ also said they were capable of using LMS (learning management system) to conduct the classes. The data show that the teachers used email to manage students' works although some of them have been familiar with the LMS platform. Further, they (66.1\%) reported that their school provided training in using technology for distance learning including the LMS training, but some of them $(33.9 \%)$ did not get it from their schools. Many of them (56.5\%) never took any professional training in digital learning and some $(43.5 \%)$ had the training. Most teachers (54.8\%) attended some trainings held by their schools and few attended trainings held by the government (16.1\%). Almost all of them $(91.9 \%)$ believe that technology can develop student's competence and few $(8.1 \%)$ said that it will not help students in learning.

\subsection{Teacher's Perception of Digital Learning}

To the teachers, technology can promote the student's motivation in learning, but few of them share different thoughts. Many studies claim that technology is potentially enhancing student's motivation and engagement in learning (Adukaite, Zyl, Er \& Cantoni, 2017). In this case, teachers have a role to harness the emergent technology to motivate students in learning for their future (Setyosari, 2015). Further, they pointed out that being independent in learning allows the students to adapt the learning into their own style. The greater demands of flexibility and autonomy in students' learning will drive teachers to change their method (teacher-centered lecture) and provide more freedom to learners (Sung, Chang, \& Liu, 2016). A teacher opined:

"My students were excited to learn (from mobile technology) and the duration set up in the learning application made students diligent to learn." (T1)

Another teacher observed:

"Online learning is a way of learning that is desirable for today's learners. They can develop themselves more by learning through the internet" and "Distance learning can replace classroom learning. Moreover, it (technology) can motivate students to read for the sake of enhancing their literacy." (T3)

Differently, not all teachers shared the same perspective that mobile technology gives a positive impact on students' affective side. Few teachers doubted that technology can motivate students in learning. Some teachers were concerned about the distraction that might divert the students from learning (Abidin et al., 2017) since they could not control the students' technology usage in the learning. They also related learning motivation to the student's characteristics as not all of them would be responsible for the learning. Students might do instant processes in learning, for instance they may copy-paste works from the internet. A teacher reflected:

'Mobile technology has not maximally improved my students' motivation and their achievement in learning because we cannot control them when using electronic media." (T2)

Another teacher lamented:

"Students have their own different characters and motivation in learning independently. They may copy-paste their works. We found such cases." (T4)

The teachers also believed that digital learning will shape the students' independence in learning and become more autonomous. In line with the perception, a study on teachers' perception of the use of mobile technology found that mobile technology made students more independent in learning (O'Connor \& Andrews, 2018). A teacher opined:

"Students can be independent (in learning). Students can learn independently in their own way and pace." (T1) 
Further, they pointed out that being independent in learning allows the students to adapt the learning into their own style. The greater demands of flexibility and autonomy in students' learning will drive teachers to change their method (teacher-centered lecture) and provide more freedom to learners (Sung et al., 2016). Several studies have noted the potentials afforded to learners through the use of mobile devices, such as enhanced learning that caters to all styles of learning (Mann, Medves, \& Vandenkerkohf, 2015). Mobile technology as the part of digital learning has been proven to promote autonomous learning (Gerger, 2014). It allows learners to be a manager of their own learning, to establish their learning goals, until they do their final assessment of their own learning (Boticki, Baksa, Seow, \& Looi, 2015). In other words, it will help learners to be more self-directed in their own learning (Rashid \& Asghar, 2016). A teacher spoke:

"Children have the freedom to explore their potentials." (T4)

The teachers declared that technology creates an easy learning environment for students. They will not feel reluctant to ask questions and join into a discussion in a virtual platform rather than in the classroom discussion. Thus, students enjoyed learning more in the digital world as they feel safe and not afraid to make mistakes. It is due to the ability of mobile technology to increase effortless informal learning by providing quick and easy access to information (Domingo \& Gargante, 2016). A teacher voiced:

"Mobile technology provides students with opportunities to actively participate in learning. Even, students who are introverted or passive in the class actively participated in this online activity. They were not ashamed or afraid to ask questions." (T3)

"They found it more enjoyable to learn the materials." (T2)

However, the teachers reflected that in some cases, technology will not be able to help students much in learning. The lack of technology usage in learning was related to poor infrastructure support (Abidin et al. 2017). The teachers reported that some of the students could not afford the mobile technologies (as their personal phone) or they possessed one but had no or had only limited access to the internet. They found that some students were not technologically literate and few students still needed some guidance in using technology to learn as they were not familiar with the technology. Two teachers described:

"Some of my students were not equipped with proper technology for learning. Some needed to wait for their parents to come home from work for accessing the phone" (T4)

"In this case, my students still needed to learn how to use technology in their learning. Even, some of them did not know how to use Google Classroom. They needed assistance in accessing the learning materials through this platform. Besides, they still had a low ability in self-directed learning. To me, a classroom meeting is my first choice." (T5)

Teachers also confessed that technology may not make any changes in student's competence if teachers are lack of pedagogical knowledge. Material clarity developed and provided by the teachers in the platform/ technology is crucial. Teachers need to consider not only the material quality but also how to deliver it through the technology. Here, the teacher's pedagogical knowledge plays an important role. Not only material, the teachers reiterated that feedback is also the core of distance learning. Assignments and exercises will mean nothing to students learning without comprehensive feedback from the teachers. A teacher described:

"Mobile technology won't enhance students' competence if the teachers didn't provide clear material and feedback. I think it only improves students' competence at around 5\%. But for the clever ones, it will be belpful." (T5)

\section{Discussion}

The study found that the teachers perceived they were ready to manage teaching in a digital platform. Most of them had self-initiative to take up the technology in their teaching before the school's regulation. It indicates that the teachers have seen the potential of mobile technology in learning and add up their 
motivation. Consequently, many of them have been regularly integrating technology into their classes. In terms of facilities, almost both teachers and students possessed mobile technologies and access to the internet to support the teaching and learning process. Most of them were also familiar with the basic skills in digital technology like using email and managing a learning management system like Google Classroom. Yet, they also presented a good pedagogical aspect of leveraging technology in their teaching. They actively conducted an online discussion and consistently gave feedback on students' learning. In this study, teacher readiness was discussed based on three aspects namely technological, pedagogical, and psychological aspects (Abidin et al. 2017).

This study rejects the perceptions about the low level of teacher awareness of utilizing technologies in their teaching (Yusri \& Goodwin, 2013; Copriady, 2014). In fact, the teachers showed self-initiative to integrate technology in their teaching and many of them have already utilized technology for one until five years. Although few of them (32.3\%) were using technology because of school regulation due to the current pandemic situation, this group belonged to the group that uses technology for less than one year. It may reiterate that the teachers perceived technology's potential in enhancing learning instead of disrupting the learning process (Abidin et al. 2017). Self-initiative reflected the teacher's psychological readiness as it portrays teachers' perspectives of mobile technology preferences for teaching (Stockwell, 2008). Teachers' perceptions of the impact of mobile technology in learning also reflects their beliefs about how this technology influences learning processes (Ertmer, 2005).

The teachers perceived they were technologically ready to embark digital learning during the pandemic although some concerns may need to be considered in the actual implementation. The study found that the teachers were equipped with mobile technologies and internet access. They also mentioned that most of their students had proper technologies to contribute to the teaching and learning process. Further, most of them were familiar with basic digital information platforms like email and half got used to learning management systems. However, few teachers confessed that some of their students had limited access to technology and the internet. Even, a teacher lamented that his student had a problem in using Google Classroom. These problems are mostly faced by teachers affiliated to schools located in a rural area of Yogyakarta. It indicates that a student's technological readiness is also a key consideration in the success of digital learning. It also proves that infrastructure and technology adoption remain a challenge for digital learning implementation in developing countries (Khan, Hwang, Abbas, \& Rehman, 2018). This finding revealed a gap between rural and urban school's readiness in digital learning without infrastructure adjustment in technology adoption. However, Khan's, et.al. (2018) experimental study found that with the same technology adoption, students in rural schools showed better performance compared to the urban since the rural students tended to maximize their time to make use of the technology provided as they did not have much access to that. Thus, it can be interpreted that both teacher and student technology readiness are an essential factor to the success of digital learning. The readiness is not only in terms of individual readiness but also in terms of environmental readiness (infrastructure).

In this study, the teacher's pedagogical readiness is defined from their pedagogical knowledge associated with technology. Here, pedagogical knowledge is a form of knowledge that applies to understand student's way of learning, classroom management skills, lesson planning, and student's assessment (Redmond \& Lock, 2019). Meanwhile, technology usage in learning is closely related to a teacher's belief to provide student-centered learning activities (Sung et al., 2016). Yet, in the student-centered learning theory, a teacher has roles to select tasks, assist student's collaboration, and provide formative feedback ( Pakdaman-Savoji et al., 2019). Thus, we inquired whether the teacher actively provides material, joins the discussion in student's collaboration, conducts assessment, and actively gives feedback. The finding shows that most teachers actively provided students with such activities, joined an online discussion, conducted assessments through the technology, and provided feedback. Although it was impossible to further investigate these activities due to the pandemic situation and research duration, the teachers' perceptions of this survey might represent their pedagogical readiness. However, the student's perception needs to be 
investigated to confirm the teacher's pedagogical activities, for example how the learning is managed, what kind of feedback is given, and how the assessment is implemented.

Further, although the study revealed that most of the teachers perceived they were ready to embark on digital learning and they believed in the potential of digital technology in enhancing student's learning amidst the pandemic, some of them faced some hurdles in harnessing the technology that leads to some doubts in it. Some teachers even confessed that their online classes were not effective because of students' limited access to technology and the internet, particularly those living in rural areas. It delineates a huge disparity in technological readiness between rural and urban schools. It also implies that student's readiness is also a key success of digital learning to avoid disparity between education in rural and urban settings (Khan et al., 2018). Thus, the study also uncovered that few teachers (not only in rural areas) found difficulties in managing digital learning as they found technology did not make any changes to students' learning and they admitted they did not give feedback and conduct assessment to students. In this case, the teachers TPACK (Technological Pedagogical Content Knowledge) need further investigation for the success of digital learning (Redmond \& Lock, 2019; Muhaimin, et al., 2019) in this situation.

\section{Conclusions}

The study found that generally, the teachers perceived they were ready to manage digital learning due to school closures amidst the pandemic. Teacher readiness was interpreted from their technological, pedagogical, and psychological readiness. Most of teachers were equipped and familiar with a digital platform for teaching. They also actively provided learning materials, joined a discussion, provided feedback, and conducted assessments through the technological platform. In addition, most of them had a self-initiative and positive perception to integrate technologies in teaching. However, the hurdles of the success of digital learning were coming from students' readiness, a problem particularly faced by teachers in rural areas. Students' limited access to technology and the internet creates a gap between rural and urban schools.

The adoption of appropriate choice of technology is a suggestion of this study to avoid education inequality as technology is the potential to bridge the gap in technological affordances between urban and rural areas (Khan et al., 2018). The learning process can be served through the use of simpler technology like text messaging or emails to adjust both student's and parent's technological skills. Consequently, learning tolerance through a relevant teaching method and approach is required to perform. In this case, the teacher's technological and pedagogical knowledge can be the key success of digital learning in rural areas.

The findings of this study are not without limitations. First, a few numbers of participants, as it is conducted in the middle of the pandemic situation, limits the generalizability of this study. However, the varied schools (27 schools) teachers, although dominantly from senior high school's level, provide rich point of views of teachers' experiences and perceptions in response to the digital learning activities. Second, observation of actual teaching implementation of teachers in digital learning is unable to be conducted due to health protocol issues. Third, as this study viewed the investigated issue from one viewpoint and in the form of self-reported perceptions, the result could be biased. Therefore, other alternating perspectives such as those of the students, parents, and school managers are suggestive in further research to provide a holistic view of the teachers' readiness in digital teaching and learning.

\section{Acknowledgement}

The author would like to express gratitude to School principals and LPPM of Universitas Aisyiyah Yogyakarta for their endless support during this research.

\section{Declaration of Conflicting Interests}

The author declared no potential conflicts of interest with respect to the research, authorship, and/or publication of this article. 


\section{Funding}

The author received financial support from Lembaga Penelitian dan Pengabdian Masyarakat Universitas Aisyiyah Yogyakarta for the research, authorships, and/or publication of this article.

\section{References}

Abidin, Z., Mathrani, A., Hunter, R., \& Parsons, D. (2017). Challenges of Integrating Mobile Technology into Mathematics Instruction in Secondary Schools: An Indonesian Context. Computers in the Schools: Interdisciplinary Journal of Practice, Theory, and Applied Research, 34(3),207-222. https://doi.org/10.1080/07380569.2017.1344056

Adukaite, A., Zyl, I.V., Er, S., \& Cantoni, L. (2017). Teacher perceptions on the use of digital gamified learning in tourism education: The case of South African secondary schools. Computers \& Education, 111, 172-190. https://doi.org/10.1016/j.compedu.2017.04.008

Boticki, I., Baksa, J., Seow, P., \& Looi, C.-K. (2015). Usage of a mobile social learning platform with virtual badges in a primary school. Computers and Education, 86, 120-136. https://doi.org/10.1016/j.compedu.2015.02.015

Cao, W., Fang, Z., Hou, G., Han, M., Xu, X., Dong, J., et al. (2020). The psychological impact of the COVID-19 epidemic on college students in China. Psychiatry Research, 287, 1-12. https://doi.org/10.1016/j.psychres.2020.112934

Compton, L.K. (2009). Preparing language teachers to teach language online: A look at skills, roles, and responsibilities. Computer Assisted Language Learning, 22(1), 73-99. https://doi.org/10.1080/09588220802613831

Copriady, J. (2014). Self-motivation as a mediator for teacher readiness in applying ICT in teaching and learning. The Turkish Online Journal of Educational Technology, 13(4), 115-123.

Domingo, M.G., \& Gargante, A.B. (2016). Exploring the use of educational technology in primary education: Teachers' perception of mobile technology learning impacts and applications' use in the classroom. Computers in Human Behavior, 56, 21-28. https://doi.org/10.1016/j.chb.2015.11.023

Ernes, Y. (2020). Pandemi Corona, Kemdikbud Luncurkan Program 'Belajar dari Rumah'. Retrieved from Detik News: https://news.detik.com/berita/d-4971727/pandemi-corona-kemdikbud-luncurkan-program-belajar-dari-rumah

Ertmer, P.A. (2005). Teacher Pedagogical Beleifs: The final frontier in our quest for technology integration. Educational Technology Research and Development, 53(4), 25-39. https://doi.org/10.1007/BF02504683

Gerger, K. (2014). 1:1 Tablet Technology Implementation in The Manbattan Beach Unified School District: A Case Study. California: California State University.

Getty. (2020). Virus corona: Sekolah, universitas meniadakan kelas, pemerintah Indonesia belum resmi liburkan sekolah. Available at: https://www.bbc.com/indonesia/indonesia-51769074

Gray, D.E., Ryan, M., \& Coulon, A. (2004). The training of Teachers and Trainers: Innovative practices, skills, and competencies in the use of e-learning. European Journal of Open, Distance, and E-learning, p 2.

Kemdikbud, P.W. (2020). Kemendikbud Hadirkan Program Tayangan "Belajar dari Rumab" di TV RI. Available at: https://www.kemdikbud.go.id/main/blog/2020/04/kemendikbud-hadirkan-program-tayangan-belajar-dari-rumah-di-tvri

Kemdikbud, P.W. (2020). Surat Edaran Pencegahan COVID-19 pada Satuan Pendidikan. Available at: https://www.kemdikbud.go.id/main/blog/2020/03/surat-edaran-pencegahan-covid19-pada-satuan-pendidikan 
Khan, S., Hwang, G.-J., Abbas, M.A., \& Rehman, A. (2018). Mitigating the urban-rural educational gap in developing countries through mobile technology-supported learning. British Journal of Educational Technology, 50(2), 1-15. https://doi.org/10.1111/bjet.12692

Leach, J., Ahmed, A., Makalima, S., \& Power, T. (2005). DEEP IMPACT: an investigation of the use of information and communication technologies for teacher education in the global south: Researching the issues. London: Department for International Development.

Lee, Y.N. (2020). 6 charts show the coronavirus impact on the global economy and markets so far. Available at: https://www.cnbc.com/2020/03/12/coronavirus-impact-on-global-economv-financial-markets-in-6-charts.html

Mann, E.G., Medves, J., \& Vandenkerkohf, E.G. (2015). Accessing best practice resources using mobile technology in an undergraduate nursing program. Computers, Informatics, Nursing, 33(3), 122-128. https://doi.org/10.1097/CIN.0000000000000135

Muhaimin, M., Habibi, A., Mukminin, A., Saudagar, F., Pratama, R., Wahyuni, S. et al. (2019). A sequential explanatory investigation of TPACK: Indonesian science teachers' survey and perspective. Journal of Technology and Science Education 9(3), 269-281. https://doi.org/10.3926/jotse.662

O'Connor, S., \& Andrews, T. (2018). Smartphones and mobile applications (apps) in clinical nursing education: A student perspective. Nurse Education Today, 69, 172-178.

https://doi.org/10.1016/j.nedt.2018.07.013

Pakdaman-Savoji, A., Nesbit, J. C., \& Gajdamaschko, N. (2019). The conceptualisation of cognitive tools in learning and teachnology: A review. Australasian Journal of Educational Technology, 35(2), 1-24. https://doi.org/10.14742/ajet.4704

Rashid, T., \& Asghar, H.M. (2016). Technology use, self-directed learning, student engagement and academic performance: Examining the interrelations. Computers in Human Behavior, 63, 604-612. https://doi.org/10.1016/j.chb.2016.05.084

Redmond, P., \& Lock, J. (2019). Secondary pre-service teachers' perceptions of technological pedagogical content knowledge (TPACK): What do they really think? Australasian Journal of Educational Technology, 35(3), 45-54. https://doi.org/10.14742/ajet.4214

Setyosari, P. (2015). Peran Teknologi Pembelajaran dalam Transformasi Pendidikan di Era Digital. Seminar Nasional Teknologi Pendidikan UM (218-227). Malang: Universitas Negeri Malang.

Sousa, M.J., \& Rocha, A. (2019). Digital learning: Developing skills for digital transformation of organizations. Future Generation Computer System, 91, 327-334. https://doi.org/10.1016/j.future.2018.08.048

Statistik, B.P. (2019a). Badan Pusat Statistik. Available at: https://www.bps.go.id/publication/2019/11/29/0328ba9a85b461816e917291/indeks-pembangunan-teknologi-informasi--dan-komunikasi-2018.html

Statistik, B.P. (2019b). Berapa Jumlah Peserta Didik di Indonesia? Available at: https://databoks.katadata.co.id/datapublish/2019/05/02/berapa-jumlah-peserta-didik-indonesia

Stockwell, G. (2008). Investigating learner preparedness for and usage patterns of mobile learning. ReCALL, 20(3), 253-270. https://doi.org/10.1017/S0958344008000232

Sung, Y.T., Chang, K.E., \& Liu, T.C. (2016). The effects of integrating mobile devices with teaching and learning on students' learning performance: A meta-analysis and research synthesis. Computers and Education, 94, 252-275. https://doi.org/10.1016/j.compedu.2015.11.008

Tam, G., \& El-Azar, D. (2020). World Economic Forum. Available at: https://www.weforum.org/agenda/2020/03/3-ways-coronavirus-is-reshaping-education-and-what-changes-mightbe-here-to-stay / 
Tang, Y., \& Tseng, H.W. (2013). Distance learners' self efficacy and information literacy skills. The Journal of Academic Librarianship, 39(6), 517-521. https://doi.org/10.1016/j.acalib.2013.08.008

Tsybulsky, D., \& Levin, I. (2019). Science teachers' worldviews in the age of the digital revolution: Structural and content analysis. Teaching and Teachers Education, 86, 1-12.

https://doi.org/10.1016/j.tate.2019.102921

Wang, S., \& Higgins, M. (2006). Limitations of Mobile Phone Learning. The JALT CALL Journal, 2(1), 3-14. https://doi.org/10.29140/jaltcall.v2n1.18

worldometers.info. (2020). COVID-19 Corona Virus Outbreak. Available at: https://www.worldometers.info/coronavirus/

Yusri, I.K., \& Goodwin, R. (2013). Mobile Learning for ICT Training: Enhancing ICT Skill of Teachers in Indonesia. International Journal of e-Education, e-Management, and e-Learning, 3(4), 293-296.

Yusri, I.K., Goodwin, R., \& Mooney, C. (2015). Teachers and mobile learning perception: towards a conceptual model of mobile learning for training. Social and Behavioral Sciences, 176, 425-430.

https://doi.org/10.1016/j.sbspro.2015.01.492

Zwart, D.P., Noroozi, O., Van Luit, J.E., Goei, S.L., \& Nieuwenhuis, A. (2020). Effects of Digital Learning Materials on nursing students' mathematics learning, self efficacy, and task value in vocational education. Nurse Education in Practice, 44, 102755. https://doi.org/10.1016/j.nepr.2020.102755

Published by OmniaScience (www.omniascience.com)

Journal of Technology and Science Education, 2021 (www.jotse.org)

\section{(c) (1) $(9$}

Article's contents are provided on an Attribution-Non Commercial 4.0 Creative commons International License. Readers are allowed to copy, distribute and communicate article's contents, provided the author's and JOTSE journal's names are included. It must not be used for commercial purposes. To see the complete licence contents, please visit https://creativecommons.org/licenses/by-nc/4.0/. 